\title{
Efficacy of Biopesticides against White Grub Leucopholis lepidophora (Blanchard) Infesting Sugarcane-A Field Study
}

\author{
S. B. Birajdar*, P. B. Mohite, U. B. Hole, Thamidela Meera Devi, \\ O. A. Kavitake, S. S. Kadavkar, S. R. Mande and P. S. Jadhav \\ Department of Entomology, R.C.S.M. College of Agriculture, Kolhapur- 416004, M.S., India \\ *Corresponding author
}

\begin{tabular}{|l|}
\hline Key w or d s \\
Leucopholis \\
lepidophora, \\
Metarhizium \\
anisopliae, EPN \\
\hline Article Info \\
\hline $\begin{array}{l}\text { Accepted: } \\
12 \text { April } 2021 \\
\text { Available Online: } \\
\text { 10 May 2021 }\end{array}$ \\
\hline
\end{tabular}

The experiment entitled "Efficacy of biopesticides against white grub, Leucopholis lepidophora (Blanchard) infesting sugarcane" was conducted in 2019-20 the field experiment on sugarcane ratoon with nine treatments, replicated thrice in the 'Randomized Block Design' with gross plot size $5 \times 5 \mathrm{~m}$ on farmers field Mr. Ashok Patil, At/Pt. Gudal, Tal. Radhanagari, Dist. Kolhapur with the objectives, to study the efficacy of biopesticides available in market for the management of white grub under field condition and to study combined effect of biopesticides against white grub under field condition. The treatments for field experiment consisted of Metarhizium anisopliae (Grub Guard), M. anisopliae (NBAIR - Ma4), EPN- H. indica (Grub Nash), EPN- H. indica (Solider), EPN- $H$. indica (Neema Power), Urva Pinaca, Chlorpyrifos and untreated control. In the field experiment, $M$. anisopliae(NBAIR - Ma4) + EPN (Grub Nash) recorded lowest clump mortality about 10.81 per cent and 11.42 per cent with that of untreated showing 24.10 per cent and 21.95 per cent in first and second application, respectively. EPN (Grub Nash) was next in the order of efficacy which recorded 12.57 and 14.46 per cent clump mortality and $M$. anisopliae(NBAIR - Ma4) followed next in order with 12.69 and 15.28 per cent of clump mortality, respectively. Treatment UrvaPinaca found to be least effective against white grub control. The next safe insecticide was Chlorpyrifos. $M$. anisopliae(NBAIR - Ma4) + EPN (Grub Nash) recorded highest cane yield. Also, considering the $\mathrm{B}: \mathrm{C}$ ratio and ICBR ratio $M$. anisopliae (NBAIR - Ma4) + EPN (Grub Nash) proves to be superior with 3.06 B:C ratio and 9.61 ICBR ratio of M.anisopliae (NBAIR Ma4) which is highest among all. Considering the above observations, $M$. anisopliae (NBAIR - Ma4) + EPN (Grub Nash) proves to be superior among all. The next best treatment in all aspects EPN (Grub Nash), followed by M. anisopliae (NBAIR- Ma4) and M. anisopliae(Grub Guard). 


\section{Introduction}

Sugarcane, Saccharum officinarum (L.) is one of the most important commercial crop belonging to the family Gramineae. Sugarcane is the main source of sugar in the world. Where as sugarcane contributes nearly about 80 per cent of world's total sugar production. India ranks second in the area as well as production of sugarcane next to Brazil. Maharashtra also ranks second in the area and production of sugarcane after Uttar Pradesh (Sugar Industry of India 2018-19).

Up till now 228 insect pest have been reported on the sugarcane crop. About 125 species of insects are known to infest the sugarcane as major pest in various part of world (Rathour et al., 2015). Economical loss in sugarcane of about 20 per cent cane yield and 15 per cent in sugar recovery due to insect pest has been estimated. Among these Coleoptera (Scarabaeidae) are the dominant group of soil pests associated with sugarcane. In India white grub is one of the fire pest of national importance. A total of 16 species were recorded during the study period under eight genera distributed in three sub families viz., Melolonthinae, Rutelinae, Dynastinae, and five tribes. Several tactics have been adopted for the management of white grub including cultural, mechanical, biological, chemical and integrated methods given by workers (Visalakshi et al., 2015). The use of biopesticides is a vital component in sustainable agriculture assumed greater significance as an important tactic in IPM due to economic viability, social acceptability and ecofriendly nature, self- perpetuating, highly persistent, cost effective (Rathour et al., 2015).

EPNs have been studied extensively for the control of white grub. Among the two entomopathogenic nematodes, S. glaseri and $H$. indica tested on different instar of white grub (Rathour et al., 2015). The entomopathogenic fungi have been reported and among these, Metarhizium anisopliae can be effectively utilized one of the components in the management of white grub. However, as not much work has been reported on effectiveness of different EPN, EPF and their combination under field condition.

Keeping in mind the seriousness of damage caused by white grub and to avoid the use of toxic chemicals on banks of river, the management is done by using market biopesticides in order to check their efficacy against white grub.

\section{Materials and Methods}

\section{Experiment Details}

\section{Field Experiment}

Crop : Sugarcane (Ratoon crop)

Cultivar : Co 86032

Design : Randomized Block Design (RBD),

No. of Treatments : Nine

No. of Replications : Three

Spacing : Row to Row $1.2 \mathrm{~m}$

Plot size $(\mathrm{m}): 5 \mathrm{~m} \times 5 \mathrm{~m}$

Drenching dates : $1^{\text {st }}$ Drenching (9/01/2020)

$2^{\text {nd }}$ Drenching (28/02/2020)

Place : Farmers field Mr. Ashok Patil, At/PtGudal, Tal. Radhanagari, Dist. Kolhapur.

\section{Procedure}

The field experiment was conducted at Gudal (Tal. Radhanagari) on farmers field. The 
required quantity of drenching solution was calibrated by drenching the control plot with water alone. Biopesticide required for drenching per plot of different concentrations were worked out at time of drenching in clean water. The drenching of biopesticide was carried by hand operated knapsack sprayer by removing nozzle. The first application of drenching was undertaken 25 days after harvesting the cane and second drenching 50 days after first application.

The care was taken, to cover all root zone area of plant, the hole near root zone with the help of crow bar (Manisegaran et al., 2011; Honakande and Mohite, 2019) and the dreanching of solution in it was carried out. The spray pump was thoroughly washed with water while switching on one treatment to another. Biopesticides, purchase from local market. The material knapsack sprayer, crow bar was collected from Entomology Section, RCSM College of Agriculture, Kolhapur.

\section{Method of recording observations for field experiment}

The observations were recorded at 5 spot with $1 \mathrm{~m}^{2}$ area per plot per replication will be selected randomly and number of damaged clumps was counted at 15, 35, and 45 days after treatment. The sugarcane clump mortality and yield was recorded and was subjected to analysis of variance.

\section{Statistical analysis}

Data on per cent mortality were corrected by Abbott's formula (Abbott, 1925) as follows.

$$
\begin{aligned}
& \text { Corrected mortality } \\
& =-\frac{\mathrm{T}-\mathrm{C}}{100-\mathrm{C}} \times 100
\end{aligned}
$$

Where,
$\mathrm{T}=$ Per cent mortality in treatment.

$\mathrm{C}=$ Per cent mortality in control.

Data on corrected clump mortality in field experiments were subjected to arcsine transformations, these transformed data were subjected to analysis of variance.

\section{Results and Discussion}

The overall performance of the treatment with M. anisopliae (NBAIR Ma4) + EPN (Grub Nash) was most effective and recorded 10.11, 10.45 and 11.88 per cent mean clump mortality when the observations were recorded at 15, 35 and 45 DAT, respectively and it was found to be significantly superior over all other treatments. The highest 21.41, 23.75 and 27.14 per cent mean clump mortality was recorded in untreated control when observations were recorded at 15, 35 and 45 DAT, respectively. Also M. anisopliae (NBAIR Ma4) + EPN (Grub Nash) show about 55.14 per cent control over untreated and found most effective in action.

The treatment EPN (Grub Nash) next in order of efficacy causing low clump mortality at 15 , 35 and 45 DAT, respectively. The effect EPN (Grub Nash) showed about 47.84 per cent control over untreated and found significantly superior followed by combination effect.

The overall performance of the treatment with M. anisopliae (NBAIR Ma4) + EPN (Grub Nash) was most effective and recorded 10.64, 11.42 and 12.19 per cent mean clump mortality when the observations were recorded at 15, 35 and 45 DAT, respectively and it was found to be significantly superior over all other treatments. The highest 19.21, 21.00 and 25.63 per cent clump mortality was recorded in untreated control when observations were recorded at 15, 35 and 45 DAT, respectively. 
Table.1 Treatment details studies for grubs under field experiment

\begin{tabular}{|c|c|c|c|}
\hline Tr.no. & Treatment & Trade name & Source with Address \\
\hline T1 & $\begin{array}{l}\text { Metarhizium anisopliae } \\
\text { (1.15 WP) }\end{array}$ & Grub Guard & $\begin{array}{c}\text { Natural Care Fertilizers } \\
\text { Gokulam Enterprises No.36, Sri Ram } \\
\text { Nagar, Pondy-Cuddaiore Road } \\
\text { Kanniakoil, Pondicherry } 607402\end{array}$ \\
\hline $\mathbf{T} 2$ & $\begin{array}{l}\text { Metarhizium anisopliae } \\
\text { (1.15 WP) }\end{array}$ & NBAIR - Ma4 & NBAIR \\
\hline T3 & $\begin{array}{c}\text { EPN } \\
(\text { Heterorhabditis indica) } \\
(1.15 \mathrm{WP})\end{array}$ & Grub Nash & $\begin{array}{c}\text { Khandelwal Biofertilizers } \\
\text { Gat No. 21/N/9, Opp.Karnataka } \\
\text { Process, Ichalkaranji-Borgaon Road, } \\
\text { A/P. BorgaonTal.Chikodi, } \\
\text { Dist.Belgavi, Karnataka-591216 }\end{array}$ \\
\hline T4 & $\begin{array}{c}\text { EPN } \\
(\text { Heterorhabditis indica }) \\
(1.15 \mathrm{WP})\end{array}$ & Solider & $\begin{array}{c}\text { Multiplex } \\
1^{\text {st }} \text { Main Road, Mahalakshimi Layout } \\
\text { Extension, Bangalore- } 580\end{array}$ \\
\hline T5 & $\begin{array}{c}\mathrm{EPN} \\
(\text { Heterorhabditis indica) } \\
(1.15 \mathrm{WP})\end{array}$ & Neema Power & $\begin{array}{l}\text { Shri- Biotech , Hyderabad } \\
\text { K N Biosciences India Sy No. 487, } \\
\text { Opp. Hot Spot Restaurant, Behind } \\
\text { SLI Power Engineers, Bachupally, } \\
\text { Qutinbullapur, Hyderabad -500 } 072\end{array}$ \\
\hline T6 & $\begin{array}{c}\text { Metarhizium anisopliae } \\
(1.15 \mathrm{WP})+\mathrm{EPN} \\
\text { (Heterorhabditis indica }) \\
(1.15 \mathrm{WP})\end{array}$ & $\begin{array}{l}\text { NBAIR - Ma4 } \\
+ \text { Grub Nash }\end{array}$ & $\begin{array}{c}\text { Natural Care }+ \\
\text { KhandelwalBiofertilizers }\end{array}$ \\
\hline T7 & $\begin{array}{c}\text { UrvaPinaca } \\
\text { (Herbal extract SL) }\end{array}$ & UrvaPinaca & $\begin{array}{c}\text { Bharti Greentech } \\
\text { New MFG. License } 17 \text { Bharati Green } \\
\text { Tech, Dist. Satara, Gal No. 629, At. } \\
\text { Sokasan, Tal. Satara, Dist. Satara. }\end{array}$ \\
\hline T8 & $\begin{array}{l}\text { Chlorpyrifos } \\
20 \% \text { EC }\end{array}$ & Dhanvan-20 & $\begin{array}{c}\text { Shubham Agro Agencies Nasia Road, } \\
\text { Indore, Madhya Pradesh. }\end{array}$ \\
\hline T9 & Untreated Control & - & - \\
\hline
\end{tabular}


Table.2 Evaluation of efficacy of biopesticides individually and in combination against grub, L. lepidophora under field condition ( $1^{\text {st }}$ application)

\begin{tabular}{|c|c|c|c|c|c|c|c|}
\hline \multirow[t]{2}{*}{$\begin{array}{l}\text { Tr. } \\
\text { No. }\end{array}$} & \multirow[t]{2}{*}{ Treatments } & \multirow{2}{*}{$\begin{array}{c}\text { Dose } \\
\text { per } 15 \\
\text { liters } \\
(\mathrm{g} / \mathrm{ml})\end{array}$} & \multicolumn{3}{|c|}{$\begin{array}{c}\text { Mean Per cent of clump } \\
\text { mortality }\end{array}$} & \multirow[t]{2}{*}{ Mean } & \multirow{2}{*}{$\begin{array}{c}\% \\
\text { Over } \\
\text { Untreated } \\
\text { Control }\end{array}$} \\
\hline & & & 15 DAT & 35 DAT & $\begin{array}{c}45 \\
\text { DAT }\end{array}$ & & \\
\hline 1 & $\begin{array}{c}\text { M. anisopliae } \\
\text { (Grub Guard 1.15 WP) }\end{array}$ & 100 & $\begin{array}{c}11.99 \\
(20.26)^{*}\end{array}$ & $\begin{array}{c}12.93 \\
(21.05)\end{array}$ & $\begin{array}{c}13.89 \\
(21.87)\end{array}$ & $\begin{array}{c}12.94 \\
(21.07)\end{array}$ & 46.30 \\
\hline 2 & $\begin{array}{c}\text { M. anisopliae } \\
\text { (NBAIR - Ma4 } 1.15 \\
\text { WP) }\end{array}$ & 100 & $\begin{array}{c}11.63 \\
(19.92)\end{array}$ & $\begin{array}{c}12.68 \\
(20.85)\end{array}$ & $\begin{array}{c}13.75 \\
(21.76)\end{array}$ & $\begin{array}{c}12.69 \\
(20.86)\end{array}$ & 47.34 \\
\hline 3 & $\begin{array}{l}\text { EPN - H. indica (Grub } \\
\text { Nash 1.15 WP) }\end{array}$ & 100 & $\begin{array}{c}11.60 \\
(19.90)\end{array}$ & $\begin{array}{c}12.46 \\
(20.66)\end{array}$ & $\begin{array}{c}13.66 \\
(21.68)\end{array}$ & $\begin{array}{c}12.57 \\
(20.76)\end{array}$ & 47.84 \\
\hline 4 & $\begin{array}{c}\text { EPN - H. indica } \\
\text { (Solider 1.15 WP) }\end{array}$ & 100 & $\begin{array}{c}12.03 \\
(20.29)\end{array}$ & $\begin{array}{c}13.10 \\
(21.20)\end{array}$ & $\begin{array}{c}13.93 \\
(21.90)\end{array}$ & $\begin{array}{c}13.02 \\
(21.14)\end{array}$ & 45.97 \\
\hline 5 & $\begin{array}{c}\text { EPN - H. indica } \\
(\text { Neema Power } 1.15 \\
\text { WP) }\end{array}$ & 100 & $\begin{array}{c}12.19 \\
(20.40)\end{array}$ & $\begin{array}{c}13.13 \\
(21.24)\end{array}$ & $\begin{array}{c}14.05 \\
(22.00)\end{array}$ & $\begin{array}{c}13.12 \\
(21.23)\end{array}$ & 45.56 \\
\hline 6 & $\begin{array}{c}\text { M. anisopliae } \\
\text { (NBAIR - Ma4 } 1.15 \\
\text { WP) + EPN - H. indica } \\
\text { (Grub Nash 1.15 WP) }\end{array}$ & $50+50$ & $\begin{array}{c}10.11 \\
(18.54)\end{array}$ & $\begin{array}{c}10.45 \\
(18.85)\end{array}$ & $\begin{array}{c}11.88 \\
(20.14)\end{array}$ & $\begin{array}{c}10.81 \\
(19.19)\end{array}$ & 55.14 \\
\hline 7 & UrvaPinaca & 100 & $\begin{array}{c}13.33 \\
(21.41)\end{array}$ & $\begin{array}{c}14.44 \\
(22.33)\end{array}$ & $\begin{array}{c}15.65 \\
(23.30)\end{array}$ & $\begin{array}{c}14.47 \\
(22.35)\end{array}$ & 39.95 \\
\hline 8 & Chlorpyrifos & 40 & $\begin{array}{c}12.54 \\
(20.72)\end{array}$ & $\begin{array}{c}13.69 \\
(21.71)\end{array}$ & $\begin{array}{c}14.83 \\
(22.64)\end{array}$ & $\begin{array}{c}13.69 \\
(21.70)\end{array}$ & 43.19 \\
\hline 9 & Untreated Control & - & $\begin{array}{c}21.41 \\
(27.52)\end{array}$ & $\begin{array}{c}23.75 \\
(29.12)\end{array}$ & $\begin{array}{c}27.14 \\
(31.35)\end{array}$ & $\begin{array}{c}24.10 \\
(29.37)\end{array}$ & \\
\hline & S.Em \pm & & 0.77 & 0.89 & 1.02 & & \\
\hline & CD $(5 \%)$ & & 2.32 & 2.68 & 3.09 & & \\
\hline & CV & & 10.31 & 10.98 & 11.56 & & \\
\hline
\end{tabular}

DAT=Days after treatment; *Figures in parenthesis are arcsine transformed value 
Table.3 Evaluation of efficacy of biopesticides individually and in combination against grub, L. lepidophora under field condition ( $2^{\text {nd }}$ application)

\begin{tabular}{|c|c|c|c|c|c|c|c|}
\hline \multirow[t]{2}{*}{$\begin{array}{l}\text { Tr. } \\
\text { No. }\end{array}$} & \multirow[t]{2}{*}{ Treatments } & \multirow{2}{*}{$\begin{array}{c}\text { Dose } \\
\text { per } 15 \\
\text { liters } \\
(\mathrm{g} / \mathrm{ml})\end{array}$} & \multicolumn{3}{|c|}{$\begin{array}{c}\text { Mean Per cent of clump } \\
\text { mortality }\end{array}$} & \multirow[t]{2}{*}{ Mean } & \multirow{2}{*}{$\begin{array}{c}\% \\
\text { Over } \\
\text { Untreated } \\
\text { Control }\end{array}$} \\
\hline & & & 15 DAT & $\begin{array}{c}35 \\
\text { DAT }\end{array}$ & $\begin{array}{c}45 \\
\text { DAT }\end{array}$ & & \\
\hline 1 & $\begin{array}{c}\text { M. anisopliae } \\
\text { (Grub Guard } 1.15 \\
\text { WP) }\end{array}$ & 100 & $\begin{array}{c}14.52 \\
(22.40)^{*}\end{array}$ & $\begin{array}{c}15.52 \\
(23.20)\end{array}$ & $\begin{array}{c}16.29 \\
(23.80)\end{array}$ & $\begin{array}{c}15.54 \\
(23.13)\end{array}$ & 29.20 \\
\hline 2 & $\begin{array}{c}\text { M. anisopliae } \\
\text { (NBAIR - Ma4 } 1.15 \\
\text { WP) }\end{array}$ & 100 & $\begin{array}{c}14.22 \\
(22.15)\end{array}$ & $\begin{array}{c}15.36 \\
(23.06)\end{array}$ & $\begin{array}{c}16.26 \\
(23.78)\end{array}$ & $\begin{array}{c}15.28 \\
(23.00)\end{array}$ & 30.38 \\
\hline 3 & $\begin{array}{c}\text { EPN - H. indica } \\
\text { (Grub Nash } 1.15 \\
\text { WP) }\end{array}$ & 100 & $\begin{array}{c}13.06 \\
(21.18)\end{array}$ & $\begin{array}{c}14.47 \\
(22.35)\end{array}$ & $\begin{array}{c}15.84 \\
(23.45)\end{array}$ & $\begin{array}{c}14.46 \\
(22.33)\end{array}$ & 34.12 \\
\hline 4 & $\begin{array}{c}\text { EPN - H. indica } \\
\text { (Solider } 1.15 \mathrm{WP})\end{array}$ & 100 & $\begin{array}{c}14.81 \\
(22.62)\end{array}$ & $\begin{array}{c}16.01 \\
(23.58)\end{array}$ & $\begin{array}{c}16.79 \\
(24.19)\end{array}$ & $\begin{array}{c}15.87 \\
(23.47)\end{array}$ & 27.69 \\
\hline 5 & $\begin{array}{c}\text { EPN - H. indica } \\
\text { (Neema Power1.15 } \\
\text { WP) }\end{array}$ & 100 & $\begin{array}{l}15.15 \\
(22.90)\end{array}$ & $\begin{array}{c}16.14 \\
(23.68)\end{array}$ & $\begin{array}{c}17.08 \\
(24.40)\end{array}$ & $\begin{array}{c}16.12 \\
(23.67)\end{array}$ & 26.56 \\
\hline 6 & $\begin{array}{c}\text { M. anisopliae } \\
\text { (NBAIR - Ma4 } 1.15 \\
\text { WP) + EPN - H. } \\
\text { indica (Grub Nash } \\
1.15 \text { WP) }\end{array}$ & $50+50$ & $\begin{array}{c}10.64 \\
(19.04)\end{array}$ & $\begin{array}{c}11.42 \\
(19.74)\end{array}$ & $\begin{array}{c}12.19 \\
(20.43)\end{array}$ & $\begin{array}{c}11.42 \\
(19.74)\end{array}$ & 47.97 \\
\hline 7 & UrvaPinaca & 100 & $\begin{array}{c}15.94 \\
(23.38)\end{array}$ & $\begin{array}{c}16.88 \\
(24.25)\end{array}$ & $\begin{array}{c}17.63 \\
(24.81)\end{array}$ & $\begin{array}{c}16.82 \\
(24.21)\end{array}$ & 23.37 \\
\hline 8 & Chlorpyrifos & 40 & $\begin{array}{c}15.75 \\
(23.53)\end{array}$ & $\begin{array}{c}16.22 \\
(23.74)\end{array}$ & $\begin{array}{c}17.29 \\
(24.56)\end{array}$ & $\begin{array}{c}16.42 \\
(23.90)\end{array}$ & 25.19 \\
\hline 9 & Untreated Control & - & $\begin{array}{c}19.21 \\
(25.92)\end{array}$ & $\begin{array}{c}21.00 \\
(27.19)\end{array}$ & $\begin{array}{c}25.63 \\
(30.33)\end{array}$ & $\begin{array}{c}21.95 \\
(27.89)\end{array}$ & \\
\hline & S.Em \pm & & 0.93 & 1.03 & 1.19 & & \\
\hline & CD $(5 \%)$ & & 2.80 & 3.12 & 3.58 & & \\
\hline & CV & & 10.92 & 11.33 & 12.00 & & \\
\hline
\end{tabular}

DAT=Days after treatment; *Figures in parenthesis are arcsine transformed value

The treatment with $M$. anisopliae (NBAIR Ma4) + EPN (Grub Nash) show about 49.97 per cent control over untreated and found most effective in action.

The treatment EPN (Grub Nash) next in order of efficacy causing low clump mortality at 15 , 35 and 45 DAT. The effect EPN (Grub Nash) showed about 34.12 per cent control over untreated and found significantly superior followed by combination effect.

The per cent over control of EPN (Grub Nash) treatment was more than all over the treatment followed by $M$. anisopliae (NBAIR Ma4) and M. anisopliae (Grub Guard), respectively. The mortality of clump in the untreated control may be due to the rough handling during 
experiment. Three different entomopathogenic fungi viz., $M$. anisopliae, $B$. bassianaand $B$. brongniartii against third instar grub proved pathogenic to L. lepidophora of white grub (Mane and Mohite, 2015) and concluded that among the three entomopathogenic fungi $M$. anisopliae was found to be the most effective.

The entomopathogenic nematodes like $H$. indica and $S$. carpocapsae reported effective against second instar grubs of $H$. serrate (Fab.) infesting sugarcane under laboratory bioassay studies by (Supekar and Mohite, 2013). Among them they found that the EPN, $H$. indica to be the most effective for first, second and third instar grubs of $L$. lepidophora..

The M. anisopliae was found significant in reducing the white grub population than other treatments at 15 DAT and at 30 DAT (Douressamy et al., 2018) concluded $M$. anisopliae with highest per cent reduction of white grub (85.7\%).

EPN can be used as one of component in IPM of arecanut white grub with imidacloprid for its effective management Naik et al., (2018).Under such situation the combination of nematode and fungus have exceptional potential as a curative control agent for white grub because of the ability of nematode to penetrate and that of fungal to multiply in host ultimately results in increasing mortality in white grub.

The treatment with $M$. anisopliae (NBAIR Ma4) + EPN (Grub Nash) at the dose of $50 \mathrm{~g}$ $+50 \mathrm{~g}$ per fifteen liters was found to be promising against white grub, L. lepidophora B. infesting sugarcane under field condition.

The EPN (Grub Nash) is found to be next in order of efficacy after treatment with $M$. anisopliae (NBAIR Ma4) + EPN (Grub Nash).
The application of chemical insecticides and pesticides on the banks of river causes the water pollution to the next villages and also creates the chances of resistance development in pest. Combined use of biopesticides can increase the efficacy of control by reduction in amount of insectides, pesticides, also minimizes chances of pest resistance and help in reduction of water and environmental pollution.

\section{References}

Abbott, W. S., 1925. A method of computing effectiveness of an insecticide. J. Econ. Entomol. 18:265-267.

Douressamy, S., V. Ravichandran and J. Jayakumar., 2018. Field efficacy of insecticides and bioinoculants against white grub in sugarcane. Ann.Pl.Protec.Sci.26(2): 287-290.

Honakande, M. K. and Mohite, P. B., (2019) Studies on combined efficacy of biopesticides and insecticides against white grub, Leucopholis lepidophora (Blanchard) infesting sugarcane. Msc. thesis Mahatma Phule Krishi Vidaypeeth, Rahuri.

Mane P. B. and Mohite P. B., 2015. Studies on utilisation of entomopathogenic fungi against white grub, Leucopholis lepidophora (Blanchard) infesting Sugarcane. M.Sc. Thesis. Mahatma Phule Krishi Vidyapeeth, Rahuri.

Manisegaran, S., Lakshmi, S. M. and Srimohanapriya, V., 2011. Field evaluation of Metarhizium anisopliae(Metschnikoff) Sorokin against Holotrichiaserrata (Blanch) in sugarcane. J. Biopestic. 4(2): 190-193.

Naik, G. B., Maheshwarappa H. P., Rajkumar M., Kalleshwaraswamy C. M., Gowdra Nagamma and Latha S, 2019. Evaluation of entomopathogenic nematodes for the management of white grub, Leucopholis lepidophora 
(Blanchard) (Coleoptera: Scarabaeidae). Journal of Entomology and Zoology Studies.7(1):09-13.

Rathour, B., Mohite, P. B. and Gite, R. B., 2015. Bioefficacy of entomopathogenic nematode, Steinernema carpocapsae against white grub, Phyllognathus dionysius (Feb). under laboratory condition. J. of Global Bioscience. 4 (8): 3165-3170. Sugar Industry of India 2018-19 Report.

Supekar, S. and Mohite, P. B., 2013. Biocontrol potential of entomopathogenic nematodes. Heterorhabditis and Steinernema against second instar grub of white grub, Holotrichia serrata (Fab) infesting sugarcane. Journal of Global Bioscience ISSN 2320-1355. (2) 24372439.

Visalakshi, M., Bhavani, B. and Rao, S. G., 2015. Field evaluation of entomopathogenic fungi against white grub, Holotrichia consanguinea (Blanch) in sugarcane. J. Biol. Control. 29(2): 103-106.

\section{How to cite this article:}

Birajdar, S. B., P. B. Mohite, U. B. Hole, Thamidela Meera Devi, O. A. Kavitake, S. S. Kadavkar, S. R. Mande and Jadhav, P. S. 2021. Efficacy of Biopesticides against White Grub Leucopholis lepidophora (Blanchard) Infesting Sugarcane - A Field Study. Int.J.Curr.Microbiol.App.Sci. 10(05): 209-216. doi: https://doi.org/10.20546/ijcmas.2021.1005.028 